ARCHIWA - KanCELARIE - ZBIORY

NR 2 (4)/2011

\title{
MateriaŁY Do BIBLIOGRAFII ARCHIWISTYKI POLSKIEJ ZA ROK 2009 - UZUPEENIENIE
}

\section{OPRACOWANIA INFORMACYJNE I EDYCJE ŹRÓDEE}

Inwentarz akt wydziatów $i$ studiów Uniwersytetu Jana Kazimierza we Lwowie do roku 1939, t. 1, oprac. J. Wołczański, Kraków 2009, wyd. Wydawnictwo Naukowe Uniwersytetu Papieskiego Jana Pawła II, ss. 596

Omawiana publikacja jest pierwszym tomem inwentarza materiałów archiwalnych Uniwersytetu Jana Kazimierza we Lwowie. Zostały w niej opisane archiwalia pięciu wydziałów (teologicznego, prawnego, lekarskiego, humanistycznego i matematyczno-przyrodniczego) lwowskiego uniwersytetu wytworzone do 1939 r., a przechowywane obecnie w zasobie Państwowego Obwodowego Archiwum we Lwowie.

Polonika hagiograficzne w Archiwum Kongregacji ds. Kanonizacji, cz. 1: Jakub Strepa, Kinga, Salomea, oprac. J. Królikowski, Tarnów 2009, wyd. Wydawnictwo Diecezji Tarnowskiej „Biblos”, ss. 119

Kolejny, bo już piąty, tom serii wydawniczej „Bibliotheca Tarnoviensis”, został poświęcony omówieniu dokumentów w procesach beatyfikacyjno-kanonizacyjnych Jakuba Strepy, Kingi i Salomei, jakie wpłynęły do kurii papieskiej w XVII i XVIII w. 63 dokumenty, które ks. Janusz Królikowski opublikował w postaci regestów oraz in extenso, są obecnie przechowywane w Archiwum Kongregacji ds. Kanonizacji w Watykanie. Autorką słowa wstępnego jest Aleksandra Witkowska OSU (s. 15-16), a ks. Janusz Królikowski, oprócz 
przygotowania edycji archiwaliów, napisał tekst o doktrynalno-kulturowych aspektach kultu świętych w Polsce w XVII i XVIII w. w świetle materiałów hagiograficznych z Archiwum Kongregacji ds. Kanonizacji (dawniej Świętej Kongregacji Obrzędów) (s. 17-29).

\section{ZBIORY STUDIów}

Dokumentacja nieaktowa w instytucjach nauki i kultury 25-27 maja 2008 Kielce-Jodtowy Dwór. XVI Konferencja Sekcji Archiwów Szkót Wyższych, Instytucji Naukowych i Kulturalnych Stowarzyszenia Archiwistów Polskich, red. M. Marcinkowska, Kielce 2009, wyd. Wydawnictwo Uniwersytetu Humanistyczno-Przyrodniczego Jana Kochanowskiego, ss. 164, ilustr.

Jak wyraźnie mówi o tym tytuł, tom zawiera materiały z konferencji zorganizowanej w maju 2008 r. przez Sekcję Archiwów Szkół Wyższych, Instytucji Naukowych i Kulturalnych SAP. Znalazło się w nim 17 referatów i krótka informacja na temat regałów przesuwnych produkowanych przez firmę FAMAR SYSTEM. Wśród nich zabrakło jedynie tekstu wystąpienia Macieja Jasińskiego na temat „Czy cukierek może być dokumentem?”. Do tomu jest dołączona płyta DVD zawierająca materiały multimedialne przygotowane przez referentów do ich wystąpień oraz nagrania filmowe i zdjęcia z przebiegu obrad.

K. Kozioł, Efektywne rozwiązania dla archiwum - nowoczesny system regatów przesuwnych $z$ napędem korbowym i elektrycznym "Compactus" oferowany przez firmę FAMAR SYSTEM, s. 17-18; M. Pawelec, Dokumentacja nieaktowa w Katolickim Uniwersytecie Lubelskim Jana Pawta II, s. 19-25; K. Dagga, B. Ząbczyk-Chmielewska, Życie studenckie poza teczką: dokumentacja $i$ archiwalia organizacji studenckich Politechniki Gdańskiej w zbiorach Pracowni Historii PG oraz Archiwum PG, s. 27-44; D. Klemantowicz, Dokumentacja nieaktowa $w$ zbiorach archiwum a powstanie muzeum uniwersyteckiego [przede wszystkim Uniwersytetu Łódzkiego], s. 45-52; P. Romanowski, Program Plagiat. Oczekiwania a efekty. Z doświadczeń stosowania programu w UMCS, s. 53-58; M. Marcinkowska, Elektroniczne systemy obstugi procesu dydaktycznego a problemy archiwizacji. Kwestionariusz pytań, s. 59-66; G. Lizner, Systemy obiegu dokumentów elektronicznych, s. 67-76; G. Bujak, Projekt digitalizacji zasobu Archiwum Diecezjalnego w Kielcach. Zarys problematyki, s. 77-82; A. Krzemińska, Materiaty audiowizualne na przedpolu archiwalnym - problemy gromadzenia i opracowania, s. 83-89; A. Cieślak, Tworzenie materiatów audiowizualnych - nowa funkcja archiwów naukowych?, s. 91-95; M. Jabłońska, B. Kierzkowska, Dokumentacja audialna i audiowizualna jako źródto badań dziejów uniwersytetu na przyktadzie zasobu Archiwum UMK w Toruniu, s. 97-106; K. Lange, Problem dokumentacji audiowizualnej na przyktadzie Archiwum UAM w Pozna- 
niu, s. 107-113; D. M. Kozielska, Dokumentacja fotograficzna-problemy i wyzwania, s. 115-118; D. Kwiatkowski, Kurioza w zbiorach instytutów Polskiej Akademii Nauk, s. 119-122; A. Szczepaniak, Szkice i projekty architektoniczne Wtadystawa Marconiego w Archiwum Muzeum Narodowego w Warszawie, s. 123-128; A. Grzebieluch, Medale w zbiorach Archiwum PAN, s. 129-133; G. Falkiewicz-Witek, Gietdy kolekcjonerskie antyków i pamiątek historycznych organizowane w Wojewódzkim Domu Kultury im. Józefa Pitsudskiego w Kielcach, s. 135-141; W. Lipińska, Dokumentacja nieaktowa w instytucjach nauki i kultury na podstawie ankiet do przewodnika po archiwach wybranych jednostek organizacyjnych, s. 143-150.

\section{Polsko-niemieckie dziedzictwo archiwalne źródtem do badań nad regio- nem lubuskim, red. T. Dzwonkowski, Zielona Góra 2009, wyd. Archiwum Państwowe w Zielonej Górze-Stowarzyszenie Archiwistów Polskich Od- dział w Zielonej Górze, ss. 126}

Omawiana publikacja ukazała się jako trzeci tom „Studiów, Materiałów, Konferencji Stowarzyszenia Archiwistów Polskich”. Na tom składają się artykuły archiwistów polskich i niemieckich, dotyczące głównie szeroko rozumianej problematyki źródeł archiwalnych dotyczących regionu lubuskiego.

K. Neitman, Archivbestände zur Geschichte der südöstlichen Gebiete der Provinz Brandenburg (18. Jahrhundert bis 1945) in Brandenburgischen Landeshauptarchiv, s. 11-28; S. Hartman, Archivbestände zur Geschichte der südöstlichen Gebiete der Provinz Brandenburg im Geheimen Staatsarchiv Preußischer Kulturbesitz Berlin, s. 29-48; D. A. Rymar, Materiaty archiwalne do historii pótnocnej części województwa lubuskiego w zasobie Archiwum Państwowego w Szczecinie Oddziat w Gorzowie Wielkopolskim, s. 49-62; K. Stryjkowski, Materiaty do dziejów dawnej zachodniej Wielkopolski w Archiwum Państwowym w Poznaniu, s. 63-70; R. Stelmach, Źródta do dziejów Środkowego Nadodrza w Archiwach Państwowych we Wroctawiu i Archiwum Archidiecezjalnym we Wroctawiu (do poczattku XIX wieku), s. 71-80; A. Borkowska, Gromadzenie i przechowywanie zasobu w Archiwum Państwowym w Zielonej Górze w latach 1953-2003, s. 81-106; Z. Bujkiewicz, Wartość informacyjna i wykorzystanie materiatów archiwalnych Archiwum Państwowego w Zielonej Górze, s. 107-116; M. Szatarski, Z dziejów Stowarzyszenia Archiwistów Polskich Oddziat w Zielonej Górze w latach 1964-1980, s. 117-126. 